\title{
Two new nematode species, Paragendria papuanensis sp. n. (Seuratoidea) and Rhabdochona papuanensis sp. n. (Thelazioidea), from freshwater fishes in Papua New Guinea
}

\author{
František Moravec ${ }^{1}$, Milan $\check{R}^{1} \mathbf{h a}^{2,3}$ and Roman Kuchta ${ }^{1,3}$ \\ ${ }^{1}$ Institute of Parasitology, Biology Centre of the Academy of Sciences of the Czech Republic, Branišovská 31, 37005 České \\ Budějovice, Czech Republic; \\ ${ }^{2}$ Institute of Hydrobiology, Biology Centre of the Academy of Sciences of the Czech Republic, Na Sádkách 7, 37005 České \\ Budějovice, Czech Republic; \\ ${ }^{3}$ Faculty of Science, University of South Bohemia, Branišovská 31, 37005 České Budějovice, Czech Republic
}

Key words: parasitic nematode, Paragendria, Rhabdochona, freshwater fish, Glossamia, Melanotaenia, Papua New Guinea

\begin{abstract}
Two new nematode species, Paragendria papuanensis sp. n. (Quimperiidae) and Rhabdochona papuanensis sp. n. (Rhabdochonidae), are described from the intestine of freshwater fishes Glossamia gjellerupi (Weber et Beaufort) (Apogonidae) and Melanotaenia affinis (Weber) (Melanotaeniidae), respectively, from the Sogeram River (Ramu River basin), Madang Province, northern Papua New Guinea. The former species is characterized mainly by the absence of oesophageal teeth, the presence of conspicuously inflated papillae of the last two subventral pairs, a gubernaculum, spicules 69-75 $\mu \mathrm{m}$ long, eggs measuring 57$66 \times 39-45 \mu \mathrm{m}$, and by a small body (male and female 3.2-3.7 and $5.8 \mathrm{~mm}$ long, respectively). Paragendria is considered a valid genus, to which P. aori (Khan et Yaseen, 1969) comb. n., P. guptai (Gupta et Masoodi, 2000) comb. n., P. hanumanthai (Gupta et Jaiswal, 1988) comb. n. and P. vermae (Gupta et Masoodi, 2000) comb. n. are newly transferred. Rhabdochona papuanensis differs from all congeners mainly in having hammer-shaped deirids and from individual species also in other characters. Both findings represent the first records of species of Paragendria and Rhabdochona from the Australian zoogeographical region and the first records of the representatives of these genera from fishes of the families Apogonidae and Melanotaeniidae, respectively.
\end{abstract}

Although the freshwater fauna of New Guinea is highly interesting from the zoogeographical point of view, to date there are almost no data on the helminth parasites of freshwater fishes from this region. Regarding nematodes, as far as the authors know, there is only one paper by Khalil (1984) reporting the ascaridoid Brevimulticaecum scleropagi Khalil, 1984 from the intestine of the Australian bonytongue Scleropages jardinii (Saville-Kent) (Osteoglossidae) from the Fly River in Papua New Guinea. Recent examinations of the alcohol-fixed viscera of a few specimens of Papua New Guinean freshwater fishes, the New Guinea rainbowfish Melanotaenia affinis (Weber) and the Gjellerup's mouth almighty Glossamia gjellerupi (Weber et Beaufort), revealed the presence of two new nematode species, which are described herein.

\section{MATERIALS AND METHODS}

The nematodes were recovered in situ from alcoholpreserved hosts' viscera. The fish intestines were cut open and the removed nematodes were placed in vials with $70 \%$ ethanol. For light microscopy (LM), the nematodes were cleared with glycerine. Drawings were made with the aid of a Zeiss drawing attachment. After the LM examination, 1 specimen of each species was also used for scanning electron microscopy
(SEM). The specimens were transferred to $4 \%$ formaldehyde solution and then post-fixed in $1 \%$ osmium tetroxide, dehydrated through a graded acetone series, critical point dried and sputter-coated with gold; they were examined using a JEOL JSM-6300 scanning electron microscope at an accelerating voltage of $15 \mathrm{kV}$. All measurements are in micrometres unless otherwise stated. The scientific names of fishes follow FishBase (Froese and Pauly 2008).

\section{DESCRIPTIONS}

Fam. Quimperiidae Baylis, 1930

Paragendria papuanensis sp. $\mathrm{n}$.

Figs. 1, 2

Description. Small whitish nematodes with smooth cuticle. Anterior end of body of fixed specimens dorsally bent. Oesophageal region of body slightly broader than posterior part of body. Head end rounded, without lateral lobes. Oral aperture circular, demarcated by narrow, slightly cuticularized ring and surrounded by four doubled submedian cephalic papillae and pair of lateral amphids (Fig. 2A). Buccal cavity poorly developed (Fig. 1C); bottom of mouth formed by flat surfaces of three oesophageal sectors without teeth (Fig. 2A). Broad lateral alae, widest in oesophageal region, extending along almost whole body length. Deirids large,

Address for correspondence: F. Moravec, Institute of Parasitology, Biology Centre of the Academy of Sciences of the Czech Republic, Branišovská 31, 37005 České Budějovice, Czech Republic. Phone: ++420 387775 432; Fax: ++420 385 310 388; E-mail: moravec@paru.cas.cz 
situated at about mid-distance between nerve ring and end of oesophagus. Excretory pore somewhat posterior to level of nerve ring. Oesophagus long, slender, its posterior part only slightly expanded; part of oesophagus anterior to nerve ring muscular, its posterior part muscular-glandular. Anterior end of oesophagus somewhat expanded, with slightly outlined 'pharynx' (Fig. 1C). Tail of both sexes conical, sharply pointed.

Male (3 specimens; measurements of holotype in parentheses): Body 3.22-3.71 (3.71) mm long, maximum width at oesophageal region 78-82 (82). Maximum width of lateral alae 24 (24). Oesophagus 396-486 (486) long, its maximum width 27-33 (33). Nerve ring, excretory pore and deirids 162-189 (186), 216-243 (237) and 264-315 (315), respectively, from anterior extremity. Ventral muscular precloacal sucker present (Fig. 1F). Relatively long, well developed caudal alae starting somewhat anterior to level of ventral sucker and extending posteriorly to approximately mid-length of tail (Fig. 1F, H, I). Preanal papillae: 4 pairs of subventral papillae present, of which papillae of first pair large, rounded, not included in caudal alae, situated some distance anterior to precloacal sucker (Figs. 1F, 2C); papillae of remaining pairs pedunculate, supporting caudal alae, second pair being at level of sucker, third and fourth pairs spaced between sucker and cloacal opening (Figs. 1F, 2C, F); unpaired median sessile papilla present at level of fourth subventral pair (Figs. 1H, 2C, E, F). Adanal papillae: 1 pair of subventrals (Figs. $1 \mathrm{H}, \mathrm{I}, 2 \mathrm{C}, \mathrm{E}-\mathrm{G})$. Postanal papillae: 6 pairs present, of which three being subventral and three lateral; papillae of first two subventral pairs elongate, slender, those of posterior two pairs conspicuously inflated, broad; papillae of first lateral pair situated between first and third pairs of subventrals, second pair at level of third pair of subventrals, and third pair at level of fourth pair of subventrals (Figs. 1H, I, 2B, E, G). Spicules simple, equally long, measuring 69-75 (75), with sharply pointed distal ends. Gubernaculum wedge-shaped in lateral view, 2730 (30) long. Tail conical, 126-135 (135) long, its posterior half in shape of slender spike.

Female (1 gravid specimen, allotype; measurements of 1 nongravid specimen in parentheses): Body 5.18 (2.94) $\mathrm{mm}$ long, maximum width 109 (68). Maximum width of lateral alae 27 (21). Oesophagus 540 (420) long, maximum width 45 (36). Nerve ring, excretory pore and deirids 207 (147), 258 (201) and 402 (258), respectively, from anterior extremity. Vulva situated in posterior half of body, 3.31 (1.99) $\mathrm{mm}$ from posterior end (at 64 (68) \% of body length); anterior vulval lip somewhat elevated. Vagina short, muscular, directed anteriorly from vulva. Uterus amphidelphic, uterine tubes of gravid specimen containing 22 eggs arranged in single file. Eggs oval, thin-walled, size 57-66 × 39-45. Coils of posterior ovary reaching into tail. Tail slender, 180 (138) long, ending in sharp cuticular point.

$\mathrm{T}$ y $\mathrm{p}$ e $\mathrm{h}$ o s t : Gjellerup's mouth almighty Glossamia gjellerupi (Weber et Beaufort) (Apogonidae, Perciformes).
Site of infection: Intestine.

T y p e 1 o c a 1 i t y : Wannang Brook, a small tributary of the Sogeram River (Ramu River basin), Madang Province, northern Papua New Guinea (collected in 2005).

Prevalence and intensity: 2 fish infected/ 3 fish examined; intensity 8 and 9 specimens.

De p os it io n of ty pes: Holotype, allotype and paratypes in the Helminthological Collection of the Institute of Parasitology, Biology Centre of ASCR in České Budějovice (Cat. No. N-890).

E t y m o log y: The specific name of this species relates to the name of the country of its origin, i.e., Papua New Guinea.

Comments. The general morphology of this species indicates that it belongs to the seuratoid family Quimperiidae, subfamily Quimperiinae. According to Moravec et al. (2002a, b), this subfamily includes a total of the following 15 genera: Quimperia Gendre, 1926; Gendria Baylis, 1930; Ichthyobronema Gnedina et Savina, 1930; Pingus Hsü, 1933; Paraquimperia Baylis, 1934; Paragendria Baylis, 1939; Paraseuratum Johnston et Mawson, 1940; Buckleynema Ali et Singh, 1954; Chabaudus Inglis et Ogden, 1965; Ezonema Boyce, 1971; Paraseuratoides Wang, 1984; Desmognathinema Baker, Goater et Esch, 1987; Touzeta Petter, 1987; Neoparaseuratum Moravec, Kohn et Fernandes, 1992; and Gibsonnema Moravec, Salgado-Maldonado et Aguilar-Aguilar, 2002. An additional genus Neoquimperia Wang, Zhao, Wang et Zhang, 1979 (see Wang et al. 1979), probably identical with Paragendria or Ezonema, can be considered a genus inquirendum because of a poor description of its type species. However, representatives of only eight of valid genera (Buckleynema, Chabaudus, Ezonema, Paragendria, Pingus, Quimperia and Touzeta) possess a precloacal sucker in the male. Of these, only species of Ezonema, Paragendria and Pingus are characterized by broad lateral alae extending along almost the whole body, whereas these are absent or reduced in other genera. Ezonema can be easily distinguished from the two last-named genera by the presence of conspicuously large deirids situated posterior to the oesophagus and highly reduced caudal alae in the male (Boyce 1971, Moravec and Nagasawa 1989). Consequently, the morphology of the new species most closely resembles that of Pingus and Paragendria; species of both these genera occur in East and South Asia, parasitizing mainly snakeheads (Channa spp., Channidae, Perciformes) and catfishes (Siluriformes), respectively.

Although Pingus and Paragendria (syn. Metaquimperia Karve, 1941, Neometaquimperia Agrawal, 1965 and Wuinema Yu et Wang, 1992 - see Chabaud 1978, Moravec et al. 2002a) are similar, they have mostly been considered valid (Ivashkin and Khromova 1976, Chabaud 1978, Soota 1983, Sood 1989). The latter genus allegedly differs from the former in that the oesophagus is swollen posteriorly and the buccal cavity is present but weakly developed (vs. oesophagus cylindri- 

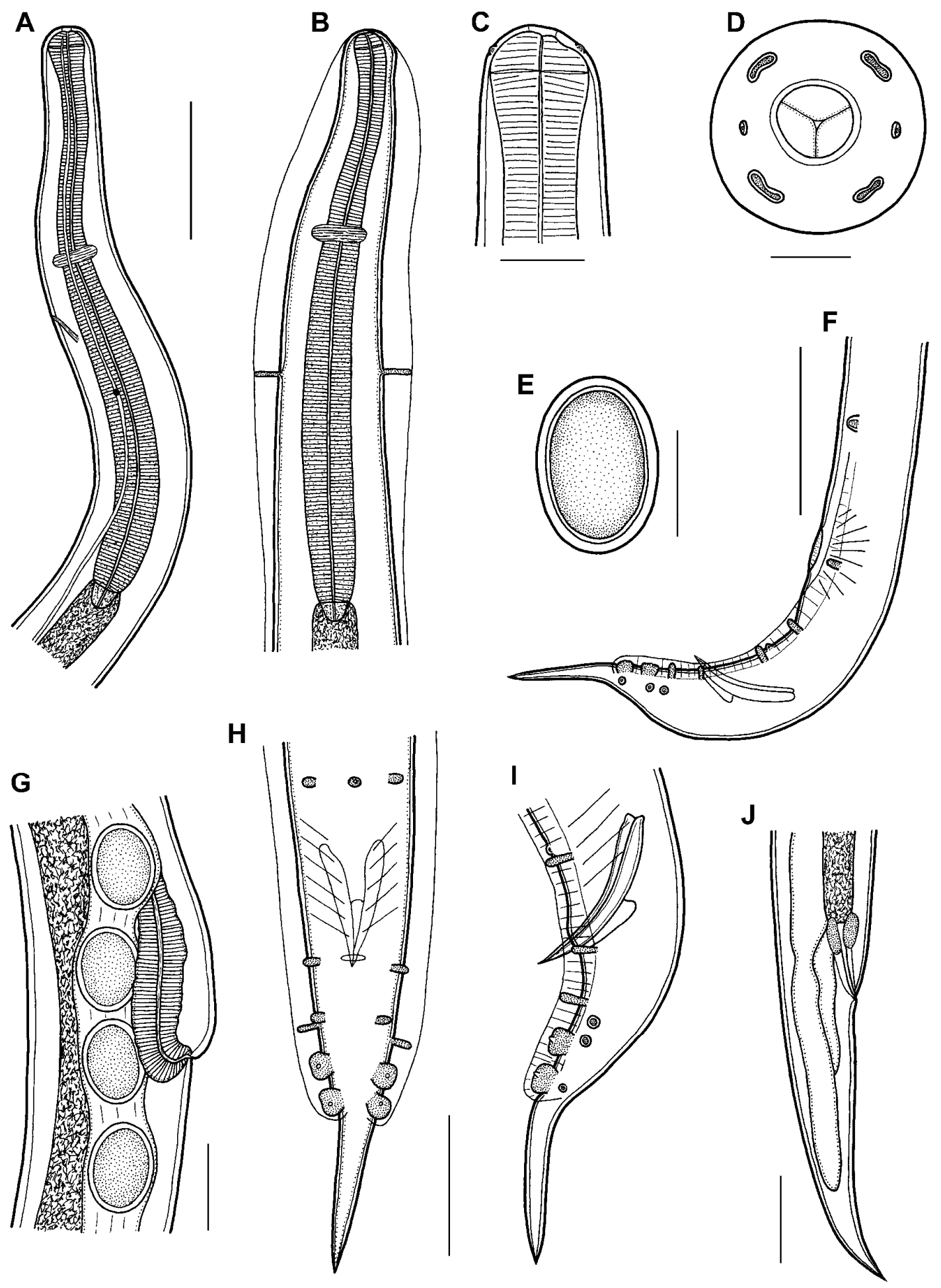

Fig. 1. Paragendria papuanensis sp. n. A, B - anterior part of body, lateral and dorsoventral views; $\mathbf{C}$, D - cephalic end, lateral and apical views; $\mathbf{E}$ - egg; $\mathbf{F}$ - posterior part of body of male, lateral view; $\mathbf{G}$ - region of vulva, lateral view; $\mathbf{H}, \mathbf{I}$ - caudal end of male, ventral and lateral views; $\mathbf{J}$ - tail of female, lateral view. Scale bars: A, B, F = $100 \mu \mathrm{m} ; \mathrm{C}, \mathrm{G}-\mathrm{J}=50 \mu \mathrm{m} ; \mathrm{D}=10 \mu \mathrm{m} ; \mathrm{E}=$ $30 \mu \mathrm{m}$. 
cal, buccal cavity absent) (Chabaud 1978, Soota 1983). However, in our opinion, these features are not probably of generic importance. Moreover, the situation is further complicated by the fact that practically all species of Paragendria are poorly described.

Gupta and Masoodi (2000) synonymized Paragendria with Pingus, but because descriptions of practically all species listed in Paragendria are poor and there seem to be some taxonomically important differences between representatives of both these genera (e.g., in the character of caudal alae and genital papillae), this synonymy can be considered questionable. Moreover, while redescribing Pingus sinensis Hsü, 1933, a type species of the genus, Moravec and Sey (1988a) found that it differed from the newly collected Paragendria sp. from a catfish in Vietnam in having distinct lateral lobes on the cephalic end and in some other features. Therefore, for the time being, until a detailed comparison of the type species of both these genera is performed, Paragendria should be accepted as a valid genus, to which the new species is now assigned. Considering mainly the host types (catfishes), the species originally inadequately described as Pingus aori and $P$. guptai are transferred to this genus as Paragendria aori (Khan et Yaseen, 1969) comb. n. and P. guptai (Gupta et Masoodi, 2000) comb. n.; moreover, P. aori was described from the same host species as $P$. macronis, the type species of Paragendria, and may well be identical with the latter, whereas $P$. guptai possesses conspicuously large postanal papillae of the two last subventral pairs, a feature typical of Paragendria spp.

The genus Paragendria was created by Baylis (1939) for the species originally described by Stewart (1914) as Heterakis macronis from Sperata aor (Hamilton) (Bagridae, Siluriformes) in India. Subsequently, additional 22 nominal species have been assigned to it mainly from catfishes in India, Bangladesh and China: P. callichroi (Karve, 1941); P. bagarii (Karve, 1941); P. baylisi Klera, 1955; P. vittatusi (Agrawal, 1965); P. buckleyi (Agrawal, 1965); P. wallagonia (Sood, 1968); P. aori (Khan et Yaseen, 1969); P. seenghalai (Rai, 1969); P. madhurai (Sood, 1973); P. lucknowia Gupta et Verma, 1976; P. gomtii (Gupta et Bakshi, 1979); P. vagrae (Arya, 1979); P. kanpurensis (Tripathi, 1982); P. indica (Gupta et Srivastava, 1983); P. tori (Gupta et Srivastava, 1983); P. tewarii Gupta et Naqvi, 1985; P. chauhani (Misra et Tiwari, 1986); P. ophiocephali (Gupta et Jaiswal, 1986); P. hanumanthai (Gupta et Jaiswal, 1988) comb. n. (syn. Metaquimperia hanumanthai Gupta et Jaiswal, 1988); P. mysti (Yu et Wang, 1992); P. guptai (Gupta et Masoodi, 2000); and P. vermae (Gupta et Masoodi, 2000) comb. n. (syn. Metaquimperia seenghali Verma, 1971) (see Soota 1983, Gupta and Jaiswal 1988, Sood 1989, Gupta and Masoodi 2000, Arthur and Ahmed 2002, this study). However, as it has been mentioned above, almost all of them are poorly described and can be considered species inquirendae. Although a few species were synonymized with others (see Sood 1989), all this group of species remains confused, probably with frequent species and generic misidentifications. The only solution of this unsatisfactory situation will have to be a taxonomic revision mostly based on newly collected topotypic materials.

Because of unreliable data on the morphology of the above-mentioned species of Paragendria, it is highly problematic to compare the new species with those previously established. However, 16 species of Paragendria ( $P$. bagarii, P. buckleyi, P. callichroi, $P$. chauhani, $P$. gomtii, $P$. indica, $P$. kanpurensis, $P$. lucknowia, P. madhuai, P. ophiocephali, P. seenghalai, $P$. tori, $P$. vagrae, $P$. vermae, $P$. vittatusi, $P$. wallagonia) are reported to possess three or six small teeth in the mouth, which are absent in $P$. papuanensis. A very characteristic feature of the new species is the presence of conspicuously large postanal papillae of the two last subventral pairs (Figs. 1F, H, I, 2B, E-G). Of the previously described species of Paragendria, such papillae were illustrated only by Stewart (1914) for P. macronis from Sperata aor in Lucknow, India and they are also visible on the drawings of $P$. baylisi and $P$. vermae, both from Sperata seenghala in Lucknow (Sood 1989), in P. mysti from Mystus macropterus (Bleeker) from China (Yu and Wang 1992), and in P. guptai from Mystus tengara (Hamilton) (type host) and Rita rita (Hamilton) from Kanpur, India (Gupta and Masoodi 2000). However, in contrast to the new species, P. macronis is characterized by the absence of a gubernaculum, a preequatorial vulva and by five pairs of preanal papillae, whereas $P$. baylisi and $P$. vermae differ in distinctly longer spicules (90-110 and 93-120 vs. 69-75 $\mu \mathrm{m})$, less numerous ( 9 pairs) and differently arranged caudal papillae, and in considerably larger body measurements. Paragendria mysti differs in the absence of caudal alae in the male, longer spicules $(88-98 \mu \mathrm{m})$ and larger body (male $5.8 \mathrm{~mm}$, female $6.6-8.6 \mathrm{~mm}$ long), whereas $P$. guptai in having allegedly no cervical alae, two median preanal papillae, shorter spicules $(58-64 \mu \mathrm{m})$, the excretory pore situated posterior to deirids, and larger body (male 5.7, female $6.5-8.3 \mathrm{~mm}$ ). Consequently, the nematodes of the present material are considered to belong to a new species. Paragendria papuanensis is the first species described from fish of the family Apogonidae and the first representative of Paragendria from the Australian zoogeographical region. Fish species of the genus Glossamia occur in fresh waters of New Guinea and Australia (Nelson 2006, Froese and Pauly 2007). Glossamia gjellerupi is distributed in Irian Jaya, Indonesia and Papua New Guinea; it is common in major river systems and small independent coastal drainages between Lae and Mamberamo basin (Allen 1991). 


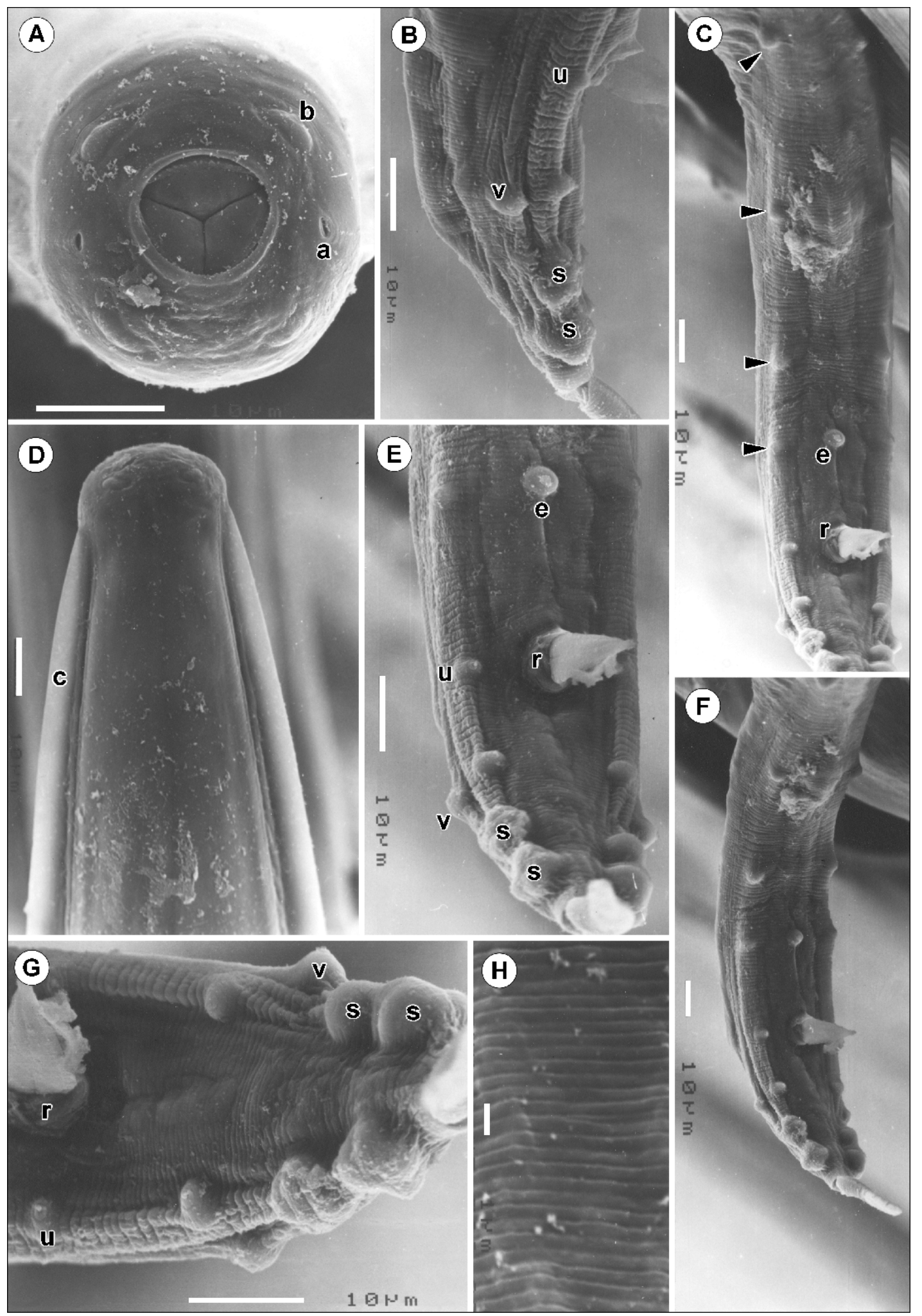

Fig. 2. Paragendria papuanensis sp. n., scanning electron micrographs. A - cephalic end, apical view; B - male tail, region of postanal papillae, lateral view; $\mathbf{C}$ - distribution of papillae in precloacal region, ventral view (arrowheads indicate subventral preanal papillae); D - anterior end of body, dorsoventral view; $\mathbf{E}$ - region of cloacal opening, ventral view; $\mathbf{F}$ - posterior end of male, subventral view; $\mathbf{G}$ - distribution of postanal papillae, ventral view; $\mathbf{H}$ - detail of transversal annulations on cuticle. Abbreviations: $\mathrm{a}$ - amphid; $\mathrm{b}$ - double cephalic papillae; $\mathrm{c}$ - cervical ala; $\mathrm{e}$ - unpaired median preanal papilla; $\mathrm{r}$ - cloacal opening; $\mathrm{s}$ - inflated subventral papilla of two last pairs; $\mathrm{u}$ - adanal subventral papilla; $\mathrm{v}$ - lateral postanal papilla. Scale bars: A-G = $10 \mu \mathrm{m} ; \mathrm{H}=1 \mu \mathrm{m}$. 
Family: Rhabdochonidae Travassos, Artigas et Pereira, 1928

\section{Rhabdochona papuanensis sp. $\mathrm{n}$.}

Figs. 3, 4

Description. Medium-sized nematodes with transversely striated cuticle. Oral aperture hexagonal, surrounded by four small submedian cephalic papillae of external circle and four minute submedian papillae of internal circle; pair of lateral amphids present. Prostom funnel-shaped; small basal prostomal teeth visible in lateral view (Fig. 1F), but absent in dorsoventral view (Fig. 1G). Anterior margin of prostom armed internally with 14 small, forwardly directed teeth (3 dorsal, 3 ventral and 4 on each side, latter forming pairs). Vestibule of medium length, curved. Deirids small, hammershaped (Figs. 1E, 2C) in lateral view, situated near posterior end of vestibule (Figs. 1A, 2A). Tail of both sexes conical, with sharply pointed tail tip.

Male (1 specimen, holotype; measurements of 1 young paratype specimen undergoing last moult in parentheses): Length of body 3.43 (3.24) $\mathrm{mm}$, maximum width 95 (82). Prostom 24 (21) long and 15 (15) wide in lateral view (shed prostom of fourth-stage larva $15 \mathrm{long}$, 9 wide). Length of vestibule including prostom 93 (99). Muscular oesophagus 129 (174) long, maximum width 27 (24); glandular oesophagus 591 (960) long, maximum width 66 (63); length ratio of both parts 1:4.6 (1:5.5). Length of vestibule with prostom and entire oesophagus forms 24 (35) \% of body length. Nerve ring encircling muscular oesophagus 120 (144) from anterior extremity; excretory pore at 177 (210). Preanal papillae: 9 pairs of subventral papillae and 1 pair of lateral papillae situated between second and third subventral pairs (counting from cloacal opening). Of 6 postanal pairs of papillae, second pair lateral, remaining subventral. Longitudinal ventral cuticular ridges (area rugosa) absent. Left spicule long, 651 (513); its shaft 225 (not observed), representing $35(-) \%$ of entire spicule length; distal tip of extruded spicule distinctly expanded. Right spicule 108 (99) long, with distinct dorsal barb at distal tip. Length ratio of spicules 1:6.0 (1:5.2). Tail 135 (177) long.

Female (2 gravid specimens with immature eggs; measurement of allotype in parentheses): Length of body $7.68-8.65(8.65) \mathrm{mm}$, maximum width 122-150 (150). Prostom 30-36 (36) long and 24-27 (27) wide in lateral view. Length of vestibule including prostom 96114 (114). Muscular oesophagus 201-225 (225) long, maximum width 24-33 (33); glandular oesophagus 1.56-1.60 (1.60) mm, maximum width 90-114 (114); length ratio of both parts $1: 7.1-7.8(1: 7.1)$. Nerve ring at 105-123 (123) from anterior extremity; excretory pore not located. Vulva postequatorial, $4.37-4.60$ (4.60) $\mathrm{mm}$ from anterior extremity (at 53-57 (53)\% of body length). Vagina directed posteriorly from vulva. Eggs in uterus numerous, immature. Tail 192-204 (192) long.
T y p e h o s t : New Guinea rainbowfish, Melanotaenia affinis (Weber) (Melanotaeniidae, Atheriniformes).

Site of infection: Intestine.

Ty p e 1 o c a 1 it y: Wannang Brook, a small tributary of the Sogeram River (Ramu River basin), Madang Province, northern Papua New Guinea (collected in 2005).

Prevalence and intensity: 2 fish infected/6 fish examined; intensity 1 and 3 specimens.

D e p o s it i o n of ty pes: Holotype, allotype and paratypes in the Helminthological Collection of the Institute of Parasitology, Biology Centre of the AS ČR in České Budějovice (Cat. No. N-891).

E t y m o log y: The specific name of this species relates to the country of its origin, i.e., Papua New Guinea.

Comments. At present the nematode genus Rhabdochona Railliet, 1916 includes 91 valid species (Moravec, unpublished) parasitizing freshwater fishes in all zoogeographical regions, except for the Australian Region (Moravec 1972, 2007, Moravec and Muzzall 2007). Of them, only seven species ( $R$. acuminata (Molin, 1860), R. canadensis Moravec et Arai, 1971, $R$. decaturensis Gustafson, 1949, R. gnedini Skryabin, 1948, R. hakyi Moravec et Sey, 1988, R. hellichi (Šrámek, 1901), R. kidderi Pearse, 1936) distributed in Eurasia and North and South America are characterized by a combination of the following features as $R$. papuanensis: the left spicule exceeding $0.5 \mathrm{~mm}$, the presence of a dorsal barb on the right spicule, 14 anterior prostomal teeth, basal prostomal teeth, and a sharply pointed tail tip in the female (Moravec and Arai 1971, Moravec 1975, 1998, Moravec and Sey 1988b).

However, in addition to some other differences, all these species distinctly differ from $R$. papuanensis in the shape of deirids: whereas the deirids of $R$. acuminata and $R$. decaturensis are simple, rod-like (Moravec and Arai 1971, Moravec 1972, Cremonte et al. 2002) and those of $R$. canadensis, R. gnedini, R. hakyi, $R$. hellichi and R. kidderi are bifurcate (Moravec and Arai 1971, Moravec and Sey 1988b, Moravec 1994, 1998), the deirids of $R$. papuanensis are hammer-shaped in lateral view. In this feature, $R$. papuanensis also differs from all other species of Rhabdochona in which deirids have been described. The shape and size of deirids are considered to be one of the taxonomically most important morphological features in Rhabdochona spp. (Moravec 1972, 1975, Mejía-Madrid et al. 2007).

An important interspecific feature of Rhabdochona spp. is the presence or absence of superficial formations on the eggs, such as filaments or swellings; however, these are present only on the fully developed eggs containing larvae (Moravec 1972, 1975, 2007). Unfortunately, available specimens of $R$. papuanensis possess only immature eggs, so that this important character remains unknown in this species. Consequently, a unique feature by which $R$. papuanensis can be distinguished from all congeners is its hammer-shaped 

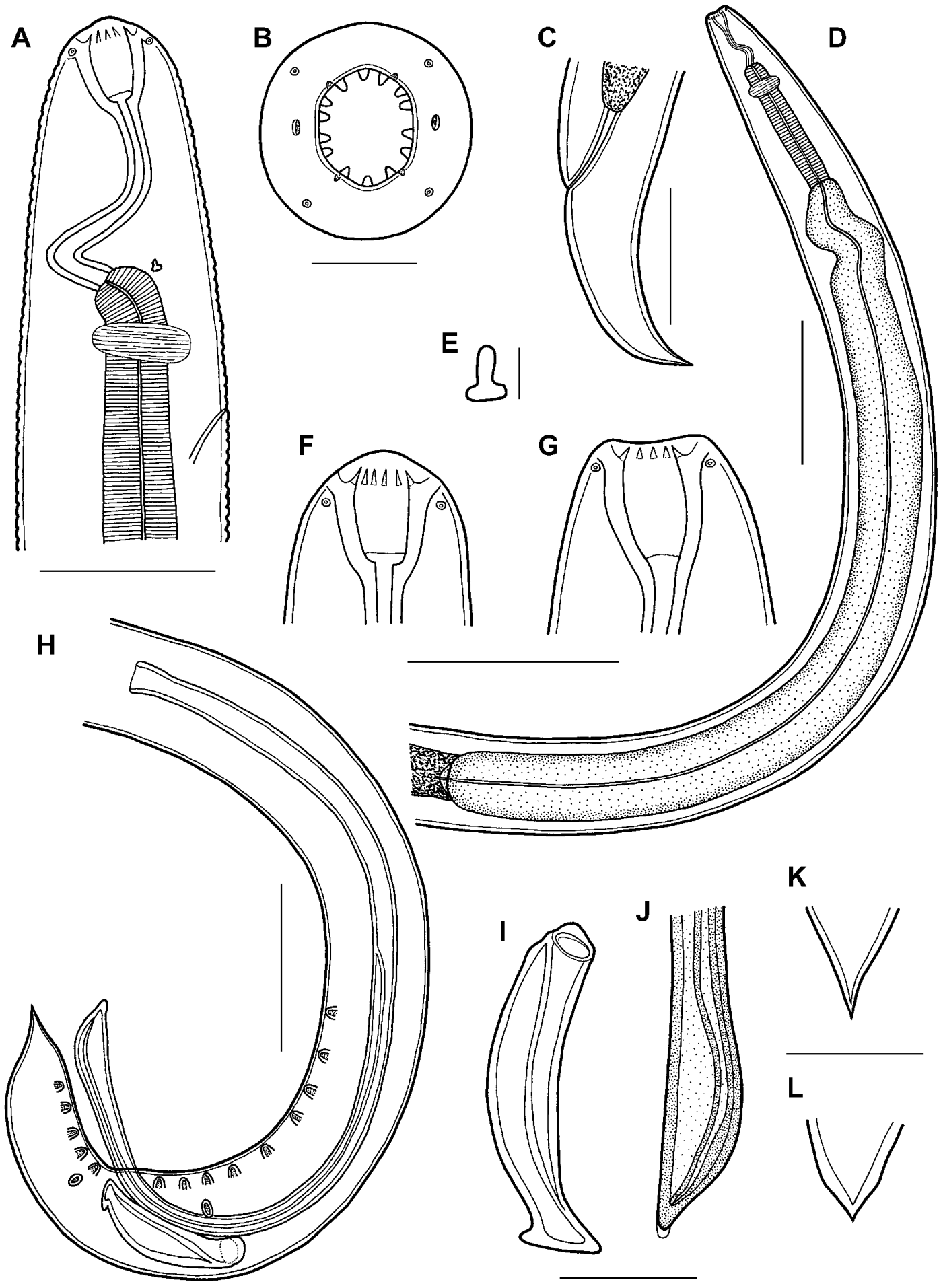

\section{G}
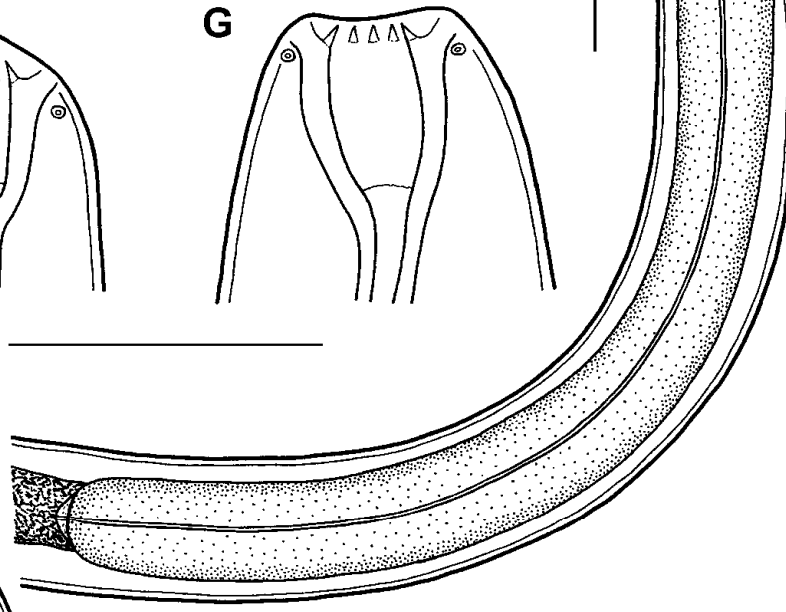

K
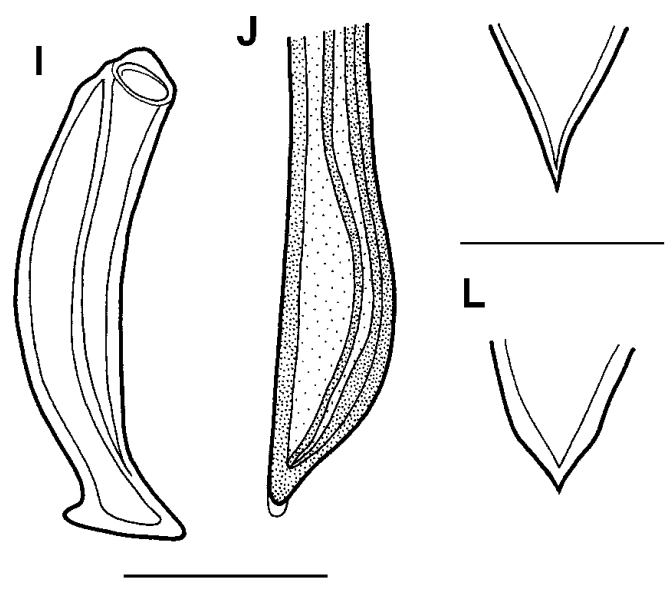

Fig. 3. Rhabdochona papuanensis sp. n. A - anterior end of female, lateral view; $\mathbf{B}$ - cephalic end, apical view; $\mathbf{C}$ - tail of female, lateral view; D - anterior part of body, dorsoventral view; $\mathbf{E}$ - deirid; F, G - prostom, lateral and dorsoventral views, respectively; $\mathbf{H}$ - posterior end of male, lateral view; I - right (small) spicule; $\mathbf{J}$ - distal end of left (large) spicule, lateral view; $\mathbf{K}, \mathbf{L}-$ tail tip of male and female, respectively. Scale bars: A, F, G $=50 \mu \mathrm{m} ; \mathrm{B}=10 \mu \mathrm{m} ; \mathrm{C}, \mathrm{H}=100 \mu \mathrm{m} ; \mathrm{D}=200 \mu \mathrm{m} ; \mathrm{E}=$ $2 \mu \mathrm{m} ; \mathrm{I}-\mathrm{L}=30 \mu \mathrm{m}$. 


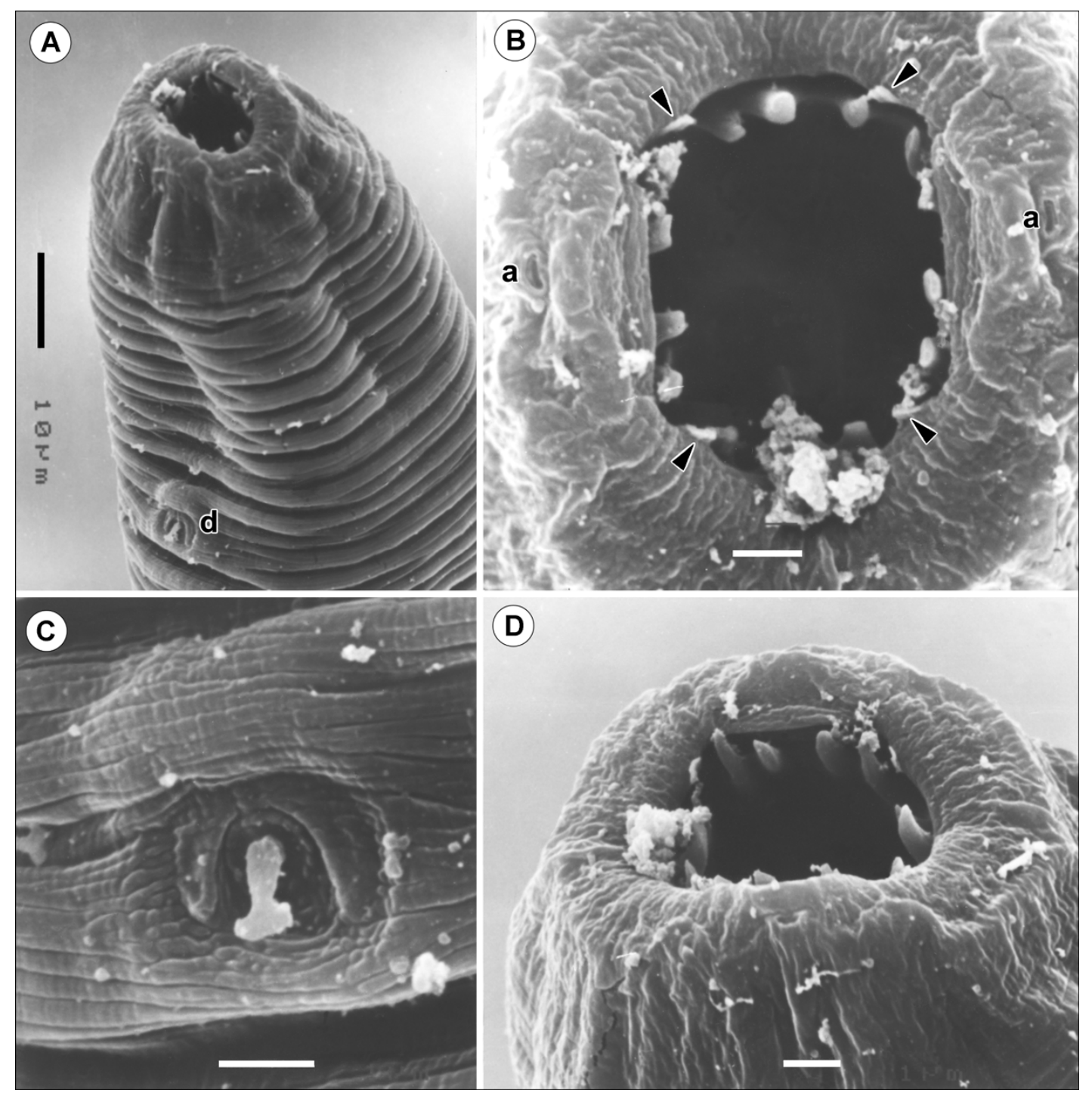

Fig. 4. Rhabdochona papuanensis sp. n., scanning electron micrographs of female. A - anterior end of body, sublateral view; $\mathbf{B}$ - cephalic end, apical view (arrowheads indicate cephalic papillae of internal circle); $\mathbf{C}$ - deirid; D - cephalic end, lateral view. Abbreviations: $\mathrm{a}$ - amphid; $\mathrm{d}$ - deirid. Scale bars: $\mathrm{B}-\mathrm{D}=2 \mu \mathrm{m}$.

deirids; from individual morphologically similar species it also differs in some other characters, such as the shape of the distal end of the left spicule, the length of spicules, the number and arrangement of caudal papillae, etc.

In spite of their frequent occurrence in facultative (paratenic, paradefinitive or postcyclic) hosts, individual species of Rhabdochona seem to be more host specific than generally believed and most species adapted themselves to fish hosts belonging to the same family, subfamily or genus (Moravec 1972, 1975, 1994, MejíaMadrid et al. 2007). Rhabdochona papuanensis is the first known species of this genus parasitizing fishes of the order Atheriniformes. Fish species of the genus Melanotaenia Gill are distributed in New Guinea and Australia (Nelson 2006). It is the first species of Rhab- dochona reported from the Australian Region. Previously three species of Rhabdochona, $R$. jaenschi Johnston et Mawson, 1940, $R$. coelorhynchi Johnston et Mawson, 1945 and $R$. beatriceinsleyae Holloway et Klewer, 1969, were reported from marine fishes from Australia and Antarctica, but these were subsequently transferred to other genera (see Moravec 1975).

Acknowledgements. Thanks are due to the staff of the Laboratory of Electron Microscopy, Institute of Parasitology, Biology Centre of the ASCR, in České Budějovice for technical assistance, and Irena Husáková, Department of Helminthology at the same Institute, for help with illustrations. This study was supported by the grant 524/06/0170 from the Grant Agency of the Czech Republic and by the research projects of the Institute of Parasitology, BC AS CR (Z60220518 and LC522) and the Faculty of Science, University of South Bohemia (MSM 6007665801). 


\section{REFERENCES}

ALLEN G.R. 1991: Field Guide to the Freshwater Fishes of New Guinea. Christensen Research Institute, Madang, Papua New Guinea, 268 pp.

ARTHUR J.R., AHMED A.T.A. 2002: Checklist of the Parasites of Fishes of Bangladesh. FAO Fish. Tech. Pap. 369/1, FAO, Rome, $77 \mathrm{pp}$.

BAYLIS H.A. 1939: The Fauna of British India, Including Ceylon and Burma. Nematoda, Vol. II. (Filarioidea, Dioctophymoidea and Trichinelloidea). Taylor \& Francis, London, 274 pp.

BOYCE N.P. 1971: Ezonema bicornis gen. et sp. n. (Nematoda: Seuratidae) from freshwater fishes of Hokkaido, Japan. J. Parasitol. 57: 1175-1179.

ChABAUD A.G. 1978: Keys to genera of the superfamilies Cosmocercoidea, Seuratoidea, Heterakoidea and Subuluroidea. In: R.C. Anderson, A.G. Chabaud and S. Willmott (Eds.), $\mathrm{CIH}$ Keys to the Nematode Parasites of Vertebrates 6. Commonwealth Agric. Bureaux, Farnham Royal, Bucks (UK), 71 pp.

Cremonte F., Navone G.T., Gosztonyi A.E., Kuba L. 2002: Redescription of Rhabdochona (Rhabdochona) acuminate (Nematoda: Rhabdochonidae) from freshwater fishes from Patagonia (Argentina), the geographical implications. J. Parasitol. 88: 934-941.

Froese R., Pauly D. (Eds.) 2008: FishBase. World Wide Web electronic publication, www.fishbase.org, version 03/2007.

GUPTA V., JAISWAL R.K. 1988: Three new nematode parasites from fresh water fishes of Lucknow. Indian J. Helminthol. 40: 64-77.

GuPTA P.C., MASOODI B.A. 2000: Synonymity of Paragendria Baylis, 1939 with Pingus Hsu, 1933, along with description of Pingus guptai new species (Nematoda: Quimperiidae) from catfishes (Osteichthyes: Bagaridage [sic]) from Kanpur, India. J. Parasit. Dis. 24: 77-82.

IVASHKIN V.M., KHROMOVA L.A. 1976: [Cucullanata and Gnathostomatata of Animals and Man and the Diseases Caused by Them.] Osnovy Nematodologii 27. Nauka, Moscow, 436 pp. (In Russian.)

KHALIL L.F. 1984: Brevimulticaecum scleropagi sp. nov. (Ascarididae: Nematoda) from the fish Scleropages jardini in Papua New Guinea. J. Nat. Hist. 18: 797-802.

MejÍA-Madrid H.H., Choudhury A., PÉREZ-PONCE De LeÓN G. 2007: Phylogeny and biogeography of Rhabdochona Railliet, 1916 (Nematoda: Rhabdochonidae) species from the Americas. Syst. Parasitol. 67: 1-18.

MORAVEC F. 1972: General characterization of the nematode genus Rhabdochona with a revision of the South American species. Acta Soc. Zool. Bohemoslov. 36: 29-46.

MORAVEC F. 1975: Reconstruction of the Nematode Genus Rhabdochona Railliet, 1916 with a Review of the Species Parasitic in Fishes of Europe and Asia. Studie ČSAV, Academia, Prague, $104 \mathrm{pp}$.
MORAVEC F. 1994: Parasitic Nematodes of Freshwater Fishes of Europe. Academia and Kluwer Academic Publishers, Prague and Dordrecht, Boston, London, $473 \mathrm{pp}$.

MORAVEC F. 1998: Nematodes of Freshwater Fishes of the Neotropical Region. Academia, Prague, 464 pp.

MORAVEC F. 2007: Some aspects of the taxonomy and biology of adult spirurine nematodes parasitic in fishes: a review. Folia Parasitol. 54: 239-257.

MoRAVEC F., ARAI H.P. 1971: The North and Central American species of Rhabdochona Railliet, 1916 (Nematoda: Rhabdochonidae) of fishes, including Rhabdochona canadensis sp. nov. J. Fish. Res. Board Can. 28: 1645-1662.

MoRAVEC F., MuZZALl P. 2007: Redescription of Rhabdochona cotti (Nematoda, Rhabdochonidae) from Cottus caeruleomentum (Teleostei, Cottidae) in Maryland, USA, with remarks on the taxonomy of North American Rhabdochona spp. Acta Parasitol. 52: 51-57.

MORAVEC F., NAGASAWA K. 1989: Observations on some nematodes parasitic in Japanese freshwater fishes. Folia Parasitol. 36: $127-141$.

Moravec F., SAlgado-Maldonado G., Aguilar-Aguilar R. 2002a: Two new nematodes, Paraseuratoides ophisterni gen. et sp. n. (Quimperiidae) and Philometra ophisterni sp. n. (Philometridae) from the swamp-eel Ophisternon aenigmaticum in Mexico. Folia Parasitol. 49: 109-117.

Moravec F., SAlgado-Maldonado G., AgUilar-Aguilar R. 2002b: Gibsonnema nom. n., a new name for the nematode genus Paraseuratoides Moravec, Salgado-Maldonado et Aguilar-Aguilar, 2002. Folia Parasitol. 49: 217.

MoraVEC F., SEY O. 1988a: Nematodes from freshwater fishes from North Vietnam. Part 3. Cosmocercoidea, Seuratoidea, Atractoidea, Heterakoidea and Ascaridoidea. Acta Soc. Zool. Bohemoslov. 52: 250-265.

MoraVeC F., SeY O. 1988b: Nematodes of freshwater fishes from North Vietnam. Part 2. Thelazioidea, Physalopteroidea and Gnathostomatoidea. Acta Soc. Zool. Bohemoslov. 52: 176-191.

NELSON J.S. 2006: Fishes of the World. Fourth edition. John Willy and Sons, Inc., Hoboken, New Jersey, 601 pp.

SoOD M.L. 1989: Fish Nematodes from South Asia. Kalyani Publishers, New Delhi - Ludhiana, 703 pp.

SoOTA T.D. 1983: Studies on Nematode Parasites of Indian Vertebrates I. Fishes. Zoological Survey of India, Occas. Pap. No. 54, Calcutta, 352 pp.

STEWART F.H. 1914: Studies in Indian helminthology, No. 1. Rec. Indian Mus. 10: 165-193 + Plts. XVIII-XXIII.

WANG P.Q., ZHAO Y.R., WANG X.Y., ZHANG J.V. 1979: Report on some nematodes from vertebrate animals in Central and South China. Fujian Shida Xuebao 2: 78-92. (In Chinese, Engl. abstract.)

YU Y., WANG G. 1992: Studies on fish parasitic nematodes of Wuinema gen. nov. and W. mysti sp. nov. Acta Hydrobiol. Sin. 16: 299-303. (In Chinese, Engl. abstract.)

Accepted 11 March 2008 